\title{
Analysis of Poverty Status of Ebonyi State Farming Households
}

\author{
Nwahia Ogechi Cordelia ${ }^{1, a, *}$, Benjamin Ahmed ${ }^{1, b}$, Onyeabor Edwin $\mathbf{N}^{2, c}$, Balogun Olusegun Stanley ${ }^{3, d}$ \\ ${ }^{1}$ Department of Agricultural Economics, Institute for Agricultural Research (IAR), Ahmadu Bello University, Zaria, Nigeria \\ ${ }^{2}$ Department of Agricultural Economics, Faculty of Agriculture, Ebonyi State University, Abakakili, Nigeria \\ ${ }^{3}$ Department of Agricultural Economics, Federal College of Forestry Mechanization, Kaduna, Nigeria
}

*Corresponding author

A R T I C L I N F O A B S T R A C T

Research Article

Poverty is a major menace in Nigeria. Therefore, the research centered on the analysis of poverty status of farming households in Ebonyi State. Multi stage and simple random sampling techniques were used to select 450 respondents for the study. Primary data were collected using electronic data capturing instrument containing the questionnaire and analyzed using descriptive statistics, Foster, Greer and Thorbeecke (FGT), and Logit regression model. The result from the study shows that $54 \%$ of the farming households in Ebonyi state were poor while $46 \%$ of them were not poor. The result further reveals that household size, dependency ratio, sex, monthly household expenditure, and farm size were the significant factors that influenced poverty status of Ebonyi state farming households. Therefore, government at the federal, state and local levels should consider socioeconomic characteristics of the farming households in the design and implementation of any poverty driven projects in order to improve their standard of living. Also, government at the various level, should consider embarking on programs to address the youth unemployment and aged members of the Nigerian society for these will reduce the dependency burden which have continued to increase the poverty level in farming households in Ebonyi state.

Keywords:

Factors

Poverty

Farming households

Foster

Greer and Thorbeecke (FGT)
Received : 07/11/2020

Accepted : 22/02/2021 godstime_ogefine@yahoo.com (iD) https://orcid.org/0000-0002-1676-4297 edwinonyeabor@yahoo.com b@ahmedben33@gmail.com d@baaseg2006@yahoo.com (i) https://orcid.org/0000-0002-5819-2768 iD https://orcid.org/0000-0001-5678-720X

\section{Introduction}

Poverty captures a wide range of dimensions which include social, economic, political, health and access to resources. Poverty has different meaning to different people depending on the type of definition used. According to Goulden and D'Arcy (2014), poverty is the inability to meet a wide range of needs which includes education, health, and basic needs. Tersoo (2013) viewed poverty as a state where an individual is not able to cater for his or her basic needs of food, clothing and shelter. Poverty manifests itself in lack of income and productive resources, low purchasing power, low life expectancy, malnutrition, lack of access to social and economic services (Adebayo, 2013; Eze, Odoh, Igwe and Mgbanya, 2019). Poverty is considered as a major menace in the Nigerian society. Nigeria is one of the poorest countries in the world, with over 80 million (or over 64\%) of her population living below poverty line (United Nation, 2017). Poverty and hunger have remained high in rural areas, and remote communities where agriculture is the mainstay (United Nation, 2017). Poverty in all its forms has affected the
Nigerian society for generations, although there have been many programmes and projects (such as Directorate for Food, Roads and Rural Infrastructure (DFRRI), better Life for Rural women, Family Economic Advancement programme (FEAP), Poverty Alleviation Programme (PAP) among others) with poverty reduction mandate implemented over the years, it appears they have not addressed the root causes of poverty (Mbanasor, Nwachukwu, Agwu, Njoku, and Onwumere, 2013). Ekong and Onye (2014), reported that $63 \%$ of Nigerian lived below the poverty line of $\$ 1$ daily even with plenty of natural resources such as oil and fertile land for agricultural production. About 112.5 million Nigerians were poor in 2010 (NBS, 2012); it increased to 119.5million in 2017 (World Bank, 2017). It is clear from existing literatures (NBS, 2012; Abur, 2014; Adetayo, 2014; World Bank, 2017: UN, 2017) that there is a growing incidence and depth of poverty in Nigeria. Recent report has it that Nigeria has overtaken India in extreme poverty ranking despite being six times smaller in population than India 
according to Khara, Hamel and Hofer (2018). Over 88 million Nigerians lived in extreme poverty in 2018, and Nigeria was named as the poverty capital of the world (Khara, Hamel and Hofer, 2018).

Ebonyi State being one of the states in Nigeria, had the least Human Development Index (HDI) in 2013 when compared with other States in the Southeast (United Nations Development Programme (UNDP), 2013). The poverty rate in the State was $56 \%$ which was higher than the national average of $46 \%$ and average of $27 \%$ for the South East in 2013 (UNDP, 2013). Recently, the poverty rate in Ebonyi State increased to $58.9 \%$ (Eze et al., 2019). About $80 \%$ of Ebonyi citizens are classified as falling below the poverty line, which is, living below the $\$ 1.9$ per day benchmark with life expectancy of 47 years (UNDP, 2013; UNDP 2016; NBS, 2017). According to NBS (2013; 2017) statistics, Ebonyi State is among the 10 poorest states in the Federation. Despite the high rate of poverty in Ebonyi State, research works on poverty in Ebonyi State concentrated on Approaches to poverty reduction like Nkwede, (2014), disregarding the factors that influence poverty, and not tailoring it to the farming households. Ume and Ochiaka, (2018) and Eze et al. (2019) looked at factors influencing poverty among rural households but limited their work to only one local government area. Some other works (Ekpe and Alimba, 2013; Nwaobiala and Ume, 2013; Nwinya, Obienusi, and Onuoha, 2014; Nwalieji, 2015) looked at the farming households in Ebonyi State but concentrated on those cultivating a particular crop and disregarded their poverty status. It is in this regard, that this study was designed to analyze the poverty status of farming households in Ebonyi State. The study tended to open a new dimension to policy makers and the government on holistic approach to poverty reduction taking into consideration the factors influencing poverty. The research work was designed to find answers to the following research questions:

- What is the socio-economic profile of farming households in Ebonyi state?

- What is the poverty status of farming households?

- What are the determinants of poverty status of farming households in Ebonyi state, Nigeria?

\section{Objective of The Study}

The main objective of the study is to analyze the poverty status of Ebonyi farming households.

The specific objective is:

- To ascertain the socio-economics profile of farming households in Ebonyi state,

- To determine the poverty status of farming households, and

- To determine the factors influencing poverty status of farming households in Ebonyi state, Nigeria.

\section{Justification for The Work}

Poverty has been the major problems in the developing countries in general. Reducing poverty in Nigeria will reposition it to where she belongs. This study will provide an understanding of the poverty status of Ebonyi farming households in Nigeria, and the information derived will be used by researchers, donor agencies, consultants and academicians as a reference for further research work. The study will be of help to the advocates and policy makers of the agricultural sector who will use it to lobby government (both local and central), development partners and donor agencies; for more resources to help eliminate poverty in Nigeria. Earlier researches (Ekpe and Alimba, 2013; Nwaobiala and Ume, 2013) have failed to captured the poverty of Ebonyi farming households. Therefore, there is limited evidence on the poverty status of Ebonyi farming households, this study will provide evidence on poverty status and factors that influences poverty of Ebonyi farming households with important policy implications in designing policies for farming households.

\section{Some Empirical works on Determinants of Poverty in Nigeria}

Researchers on determinants of poverty in Nigeria, enlisted education, age, gender, per capita expenditure among others as major poverty determinants. Ogwumike and Akinnibosun, (2013) found that socioeconomic characteristics of the household, physical assets and community factors such as location of residence and geopolitical zone were the major poverty determinant. Their major finding is that farmer's income is inversely related to the poverty status of the household, for a one per cent increase in income from farming activities reduces the probability of a farming household being poor by 16 per cent. Edoumiekumo, Karimo, and Tombofa (2013), reveals that household size, per capita expenditure on health, education and food were the important poverty determinants in Nigeria while gender, occupation, years of schooling, household size, per capita expenditure on education, health, food, and number of rooms occupied by the household were the determinants of poverty vulnerability in Nigeria. Tsue, Obekpa and Iorlamen (2013), reveals that age, farming experience and farm size were the major determinants of poverty while Duniya and Rekwot (2015), considered age, education, membership of cooperative society, farming experience and extension contact as the major determinants of poverty. But for Anyanwu (2013), age, gender and education were the major determinants of poverty. Also, Eze et al. (2019) submitted that age, sex, education, monthly income and household size were the factors influencing poverty among rural households.

\section{Methodology}

The study was conducted in Ebonyi State. Agriculture is a major occupation in Ebonyi State. An estimated 85\% of the population earn their living from agriculture. The State is blessed with moist land for growing varieties of cash and food crops such as rice, yam, cassava, maize and cocoyam as well as cash crops like cashew, cocoa and oil palm. The total land area of the State is $5,935 \mathrm{~km}^{2}$ (Obasi, Agbo and Onyenekwe, 2015). The rainfall pattern is bimodal spreading between April and November with peaks in July and September. Total annual mean rainfall is $1750 \mathrm{~mm}$ while the annual minimum and maximum rainfall range from $1700 \mathrm{~mm}$ to $1800 \mathrm{~mm}$. The temperature ranges 
from $27^{\circ} \mathrm{C}$ to $31^{\circ} \mathrm{C}$ for night and day temperatures respectively. Relative humidity is usually high at $80 \%$ during rainy season and declines during the dry season to less than 65\% ((Ekpe and Alimba, 2013). Ebonyi State is located within latitude $7^{\circ} 30 \mathrm{E}$, and $8^{\circ} 30 \mathrm{E}$ and longitude $6^{\circ}$ $40 \mathrm{~N}$ and $6^{\circ} 45 \mathrm{~N}$ of South East Zone of Nigeria. Ebonyi is made up of thirteen local government areas (LGAs) with a total population projected to be 3.1 million people in 2020 .

Multi-stage sampling procedures were used for this study. Stage one involves random selection of six (6) local government areas (LGA) out of thirteen (13) in Ebonyi State. In the second stage, two (2) communities each were randomly selected from the six LGAs to give a total of twelve (12) communities. The two (2) communities (selected on equal proportion basis) captured about $10 \%$ of the total communities in each of the Local Government Areas. In the third stage, four hundred and fifty (450) farming households were randomly selected from the lists of farming households in the twelve (12) sampled communities. Data were collected using electronic data capturing instrument containing the questionnaire. Data were analyzed using percentages, mean and frequency (descriptive statistics), Foster, Greer and Thorbeecke (FGT) and Logit Model.

\section{Model Specification}

Foster, Greer and Thorbeecke (FGT) Index

The Foster, Greer and Thorbeecke (FGT) poverty index was used to determine poverty status among the respondents. Foster, Greer and Thorbeecke is a decomposable poverty measure. If a poverty measure of a group is a weighted average of the poverty measures of the individuals in a group, then it is said to be decomposable. Foster, Greer and Thorbeecke poverty measure was adopted in this study because of its decomposable nature.

It is generally given as:

$$
\mathrm{P}_{\alpha}=\frac{1}{N} \sum_{\mathrm{i}=1}^{\mathrm{q}}\left(\frac{\mathrm{Z}-\mathrm{Yi}}{\mathrm{Z}}\right)^{\alpha}
$$

Where:

$\mathrm{P} \quad=$ Foster, Greer and Thorbecke index,

$\mathrm{N}=$ Total number of respondents

$\mathrm{q}=$ Number of respondents below the poverty line i.e poor people

$\mathrm{Yi}=$ Per capita household income of the respondent

$\mathrm{z}=$ The poverty line.

$\alpha \quad=$ Is a non-negative poverty aversion parameter $(0$, $1,2)$.

The analysis of the poverty status of the farming households was decomposed into three indicators: prevalence of poverty $\left(\mathrm{P}_{0}\right)$, poverty depth $\left(\mathrm{P}_{1}\right)$ and severity of poverty $\left(\mathrm{P}_{2}\right)$, which is empirically stated below:

$$
\mathrm{P}_{0}=\frac{q}{N}
$$

Where:

$\mathrm{P}_{0} \quad=$ Is prevalence of poverty, $\mathrm{q}$ and $\mathrm{N}$ as stated in equation 1 .

$$
\mathrm{p}_{1}=\frac{1}{N} \sum_{i=1}^{q}\left(\frac{Z-Y i}{Z}\right)
$$

Where:

$\mathrm{p}_{1}=$ Is the poverty depth, $\mathrm{z}, \mathrm{Yi}$ and $\mathrm{q}$ as stated in equation 1.

$$
\mathrm{p}_{2}=\frac{1}{\mathrm{~N}} \sum_{\mathrm{i}=1}^{\mathrm{q}}\left(\frac{\mathrm{Z}-\mathrm{Yi}}{\mathrm{Z}}\right)^{2}
$$

Where:

$\mathrm{p}_{2}=$ Is the severity of poverty, $\mathrm{z}, \mathrm{Yi}$ and $\mathrm{q}$ as stated in equation 1

\section{Poverty Line}

Per capita household income (PCHI) was adopted in this study as a measure for determining the poverty line. Per capita household income was chosen because income indicates the ability of the farming households to purchase their basic needs of life.

It is stated thus:

$$
\begin{aligned}
& \text { PCI (monthly) }=\frac{\text { total household monthly income }}{\text { adjusted household size }} \\
& \text { PCHI }=\frac{\text { total per capita income for all households }}{\text { total number of household }}
\end{aligned}
$$

The poverty line is two-third of the mean per capita household income. OECD equivalence scale was used to adjust the household size.

\section{Logit Model}

Logit model was used to determine the factors that influence poverty status of farming households in Ebonyi State. The selection of this model is in line with the studies of Giang, Wang and Yan, (2014), Yousaf, (2014) and Dorah, (2015). Logit model emanated from cumulative standard logistic distribution. It is a non-linear regression model that forces the output (predicted values) to be either one or zero. Therefore, in logit model, the dependent variable takes the value of one or zero. The model was adopted in this study because of the dummy nature in the poverty status used in this study. Poverty status in this study entails that either the farming households is poor or not poor. Variables that were included in the model are age, household size, dependency ratio, sex, household monthly expenditure, farm size, membership of association, education.

The logistic regression model is sated thus:

$$
\mathrm{P}_{\mathrm{i}}=\mathrm{f}(\mathrm{Z})=\log \frac{p i}{1-p i} \Sigma^{\mathrm{n}} \beta_{\mathrm{i}} \mathrm{Z}_{\mathrm{i}}
$$

$\mathrm{P}_{\mathrm{i}}=$ Denotes the probability that the farming households is below or above the poverty line

$\beta_{\mathrm{i}}=$ Are the coefficients

$\mathrm{Z}_{\mathrm{i}} \quad$ = Are poverty determinants variables.

The model can be written in terms of the probability of being poor as follows:

$p_{i}=\frac{\exp \left(\beta_{0}+\beta_{i} Z_{i}\right)}{\left(1+\exp \left(\beta_{0}+\beta_{i} Z_{i}\right)\right.}$

Where:

$\mathrm{p}_{\mathrm{i}} \quad$ = Is probability of being poor

$\beta=$ Are constant and $\beta_{\mathrm{i}}$ and $\mathrm{Z}_{\mathrm{i}}$ as defined in equation 7 
To illustrate it in terms of the probability of being nonpoor, it follows that:

$$
1-p_{i}=\frac{1}{(1+\exp (\beta 0+\beta i Z i)}
$$

Where:

$1-\mathrm{p}_{\mathrm{i}} \quad=$ Is probability of being non-poor

$\beta_{0}, \beta_{\mathrm{i}}, \mathrm{Z}_{\mathrm{i}}=$ Are defined in equation 7

The empirical logistic regression model is stated thus:

$$
\mathrm{Y}_{\mathrm{i}}=\beta_{0}+\beta_{1} \mathrm{Z}_{1}+\ldots \ldots \ldots+\beta_{8} \mathrm{Z}_{8}+\mathrm{e}_{\mathrm{i}}
$$

In the model:

$\mathrm{Y}_{\mathrm{i}}$ is the poverty status (a dummy variable that takes the value of $1\left(\mathrm{p}_{\mathrm{i}}\right)$ when the farming household's per capita income is below the poverty line, that is $2 / 3$ of mean per capita income and $0\left(1-p_{i}\right)$ otherwise $), e_{i}$ is the error term,

$\beta_{0}=$ constant, $\beta_{1}-\beta_{8}=$ parameters estimated

$\mathrm{Z}_{1}=$ Age (years),

$Z_{2}=$ Household size (number)

$\mathrm{Z}_{3}=$ Dependency ratio (number of independent members divided by number of dependents)

$\mathrm{Z}_{4}=\operatorname{Sex}(1$ for male and 0 for female)

$\mathrm{Z}_{5}=$ Household monthly expenditure (naira)

$Z_{6}=$ Farm size (ha)

$Z_{7}=$ Membership of organization (years of membership)

$\mathrm{Z}_{8}=$ Education (years spent in formal education).

\section{Results and Discussion}

\section{Socio-Economic Characteristics}

Analysis of the socio-economic characteristics of the farming households were carried out using mean, frequency, and percentage and presented in Table 1 . The variables selected includes sex, age, and education, household size, farm size, occupation, type of houses lived in by the respondents among others.

Table 1 reveals that majority $(67.56 \%)$ of the farming households in Ebonyi State were male while minority $(32.44 \%)$ were female. This implies that most farming households in Ebonyi State were headed by male gender. Therefore, there is gender inequality among the farming households in Ebonyi state. Age of the farmers affect the ability of the farmer to perform farming operation. The older the farmer, the less productive he/she is expected to be. Table 1 reveals that the average age of the farming households were 48 years. This implies that majority of the farming households were highly productive and were within their economic viable age. Therefore, they can make positive contribution to agricultural development. This finding is in line with Eze et al. (2019).

The results in Table 1 shows that farming households' average household size were 7 members. This means that majority of the farming households have relatively high household sizes. This is a positive indication of the availability of family labour for farm work. Education can enhance farmers' ability to make accurate and meaningful management decisions. Table 1 reveals that the average number of years spent in formal education by the farming households were 8 years. This shows that the farming households were not well educated but they had some level of formal education. This finding agrees with Ilu (2015). At the time of the survey, the average farm size of farming households were 1.8 hectares. This shows that the farming households were mainly small holder farmers (Ilu, 2015). This may be due to the land tenure system practiced in Nigeria which gives the government control of most lands.

Type of house lived in by most of the farming households were mud house - with $62.22 \%$ of them living in such houses while $31.56 \%$ of them were living in old cement houses; and only about $6.22 \%$ of them were living in modern cement houses. Further enquiry showed that $90.08 \%$ of the farming households owned their houses while only $9.92 \%$ were living in rented apartments. Information from the field work reveals that these farming households sourced their drinking water from local streams and bore whole while there is zero or few unequipped hospitals within the farming households' locality. This portrays the poverty situation in Edonyi state. About $37.11 \%$ of the farming households had farming as their only occupation and were therefore full-time farming households while majority $(62.89 \%)$ of them combined farming with other occupations, which were identified as masonry, trading, electrical works, civil service, okada and keke riding (motor bike and tri-cycle transportation), gate keeper, tailoring, hair stylist and carpentry work.

Table 1. Socio-economic characteristics of the farming

\begin{tabular}{|c|c|c|}
\hline Variables & $\mathrm{F}$ & Percentage \\
\hline \multicolumn{3}{|c|}{ Sex } \\
\hline Female & 146 & 32.44 \\
\hline Male & 304 & 67.56 \\
\hline \multicolumn{3}{|c|}{ Age } \\
\hline $21-30$ & 36 & 8.00 \\
\hline $31-40$ & 122 & 27.11 \\
\hline $41-50$ & 137 & 30.44 \\
\hline $51-60$ & 103 & 22.89 \\
\hline $61-70$ & 31 & 6.89 \\
\hline $71-80$ & 21 & 4.67 mean $=48$ \\
\hline \multicolumn{3}{|c|}{ Education } \\
\hline 0 & 77 & 17.11 \\
\hline $1-6$ & 146 & 32.44 \\
\hline $7-12$ & 168 & 37.33 \\
\hline $13-18$ & 59 & 13.11 mean $=8$ \\
\hline \multicolumn{3}{|c|}{ Household size } \\
\hline $1-5$ & 123 & 27.33 \\
\hline $6-10$ & 281 & 62.44 \\
\hline $11-15$ & 36 & 8.00 \\
\hline $16-20$ & 10 & 2.22 mean $=7$ \\
\hline \multicolumn{3}{|c|}{ Farm size } \\
\hline $0.2-1.1$ & 84 & 16.67 \\
\hline $1.2-2.1$ & 220 & 48.89 \\
\hline $2.2-3.1$ & 73 & 16.22 \\
\hline $3.2-4.1$ & 52 & 11.56 \\
\hline $4.2-5.1$ & 21 & 4.67 mean $=1.8$ \\
\hline \multicolumn{3}{|c|}{ House type } \\
\hline Mud house & 280 & 62.22 \\
\hline Cement old house & 142 & 31.56 \\
\hline Cement modern house & 28 & 6.22 \\
\hline \multicolumn{3}{|c|}{ Occupation } \\
\hline Full-time farming & 167 & 37.11 \\
\hline Farming and others & 283 & 62.89 \\
\hline \multicolumn{3}{|c|}{ Monthly per capita income } \\
\hline $3,000-10,999$ & 155 & 34.44 \\
\hline $11,000-18,999$ & 194 & 43.11 \\
\hline $19,000-26,999$ & 66 & 14.67 \\
\hline $27,000-34,999$ & 35 & 7.78 Mean $=13,202$. \\
\hline
\end{tabular}
households in Ebonyi state (Source: Field survey, 2019). 
Table 2. Poverty status of farming households in Ebonyi (Source: Field survey, 2019)

\begin{tabular}{c|ccc}
\hline Poverty Indices & Coefficient & Standard error & t-statistics \\
\hline Poverty incidence Poverty incidence & 0.54 & 0.125 & 4.33 \\
$\left(\mathrm{p}_{\mathrm{o}}\right.$ ) Poverty depth $\left(\mathrm{p}_{1}\right)$ Poverty severity & 0.20 & 0.086 & 2.33 \\
$\left(\mathrm{p}_{2}\right)$ Mean per capita income (MPI) & 0.09 & 0.016 & 5.56 \\
Poverty line 2/3 of MPI & 13202.40 & 1208.700 & 10.92 \\
\hline
\end{tabular}

Table 3. Logit result on determinants of poverty status of the respondents

\begin{tabular}{c|ccccc}
\hline Variables & Coefficient & Standard err & $\mathrm{Z}$ & $\mathrm{P}>(\mathrm{Z})$ & Marginal effect \\
\hline Age $\left(\mathrm{Z}_{1}\right)$ & 0.0012152 & 0.0162665 & 0.07 & 0.940 & 0.000222 \\
Household size $\left(\mathrm{Z}_{2}\right)$ & 0.2252834 & 0.703022 & 3.20 & 0.001 & $0.041618^{* * *}$ \\
Dependency ratio $\left(\mathrm{Z}_{3}\right)$ & 0.1878769 & 0.0819031 & 2.29 & 0.022 & $0.0343272^{* *}$ \\
Sex $\left(\mathrm{Z}_{4}\right)$ & -0.4785324 & 0.2476474 & -1.93 & 0.053 & $-0.0917188^{*}$ \\
Monthly expenditure $\left(\mathrm{Z}_{5}\right)$ & -0.0000245 & 0.000123 & -2.00 & 0.046 & $-0.000481^{* *}$ \\
Farm size $\left(\mathrm{Z}_{6}\right)$ & -0.9065575 & 0.1564552 & -5.79 & 0.000 & $-0.16564^{* * *}$ \\
Years in cooperative $\left(\mathrm{Z}_{7}\right)$ & 0.0108115 & 0.0253324 & 0.43 & 0.670 & 0.0019754 \\
Years of education $\left(\mathrm{Z}_{8}\right)$ & -0.0006797 & 0.0302778 & -0.02 & 0.982 & -0.0001242 \\
Constant & 0.1749765 & 0.8591737 & 0.20 & 0.839 & \\
No of obs $=450$ & & & & & \\
LRChi $(8)=72.31$ & & & & & \\
Prob $>$ chi square $=0.0000$ & & & & &
\end{tabular}

Others included fishing, photographing, pensioners, brick laying, garri engine operators, and wielding work. The results show some level of diversification embarked upon by the farming household. Also, Table 1 reveals that household monthly mean per capita income of the farming households were N13, 202.4. This shows that majority of the farming households were low-income earners.

Poverty Status of framing households in Ebonyi State

The households' poverty status was analyzed using three indicators; poverty incidence (Po), poverty depth (P1), and severity of poverty (P2) from FGT Index as stated in the methodology, and presented in Table 2. The FGT index was used to decompose the farming households into various poverty statuses. The procedure involves estimating the different poverty indices using the farmhousehold data set; the number of farming households that were below a poverty line, the depth and severity of poverty was calculated using poverty indices. All these three poverty measures show the prevalent, depth and severe of poverty among the farming households in Ebonyi state.

Table 2 reveals that the mean household monthly per capita income of the respondents was N13, 202.40 while poverty line was N8801.60 which was the two-third of the mean per capita income. This implies that households whose monthly per capita income were below N8, 801.60 were considered to be poor while those whose monthly per capita income were above N8, 801.60 were considered as non-poor. The monthly per capita income of the household was derived while taking into consideration the adult and children in the household. Therefore, the adjusted household size was used in this work. Table 2 shows that the poverty incidence among the framing households were 0.54. This implies that about 54 percent of the farming households were poor while 46 percent of them were nonpoor. The poverty incidence/ poverty prevalence is the head count of the number of the respondents that are poor. The prevalence of poverty shows that 54 percent of the farming households had their household's monthly per capita income below the poverty line (N8, 801.60). Table 2 shows that the poverty depth was 0.20 representing the percentage of income required to bring a poor household up to the poverty line. This shows that $20 \%$ of N8, 801.60 were required to bring a poor household to the poverty line. The severity of poverty was 0.09 . This shows that 9 percent differences exist in the income of the poor farming households. The severity of poverty shows that the poor farming households were vulnerable to poverty and therfore require attention of policy makers and the Government to bring them out of poverty. This finding is in line with Mbanasor et al. (2013).

\section{Determinants of Poverty Status of farming households in Ebonyi State}

As stated in the methodology, Logit model was used to examine the factors influencing poverty status of farming households in Ebonyi State and the result are presented in Table 3. An additional insight into the influence of these factors on poverty status of farming households were also provided by analyzing the marginal effects. The loglikelihood of -247.698 , the pseudo $\mathrm{R}^{2}$ of 0.1274 and the LR (Chi square) of 72.31 (significant at $1 \%$ level) imply that the overall model is well fitted in the data and the explanatory variables used in the model were collectively able to explain the determinant of poverty status in Ebonyi State.

Table 3 shows that among the included variables, household size $(0.22528)$, dependency ratio $(0.18788)$, sex $(-0.4785)$, monthly household expenditure $(-0.00002)$, and farm size $(-0.90656)$ were significantly influencing poverty 
status of Ebonyi State farming households while age (0.00122), years in a cooperative society $(0.01081)$, and years of formal education (-0.00068) had no significant influence on poverty status of farming households in Ebonyi.

Table 3 reveals that household size positively influenced poverty status of farming households. The coefficient of the household size is significant $(\mathrm{P}<0.01)$ at $1 \%$ level of probability. The positive coefficient of household size implies that increase in household size of the respondents, will increase poverty level and vice versa. The marginal effect shows that an additional member to the farming household will increase the probability of being poor by $4.2 \%$. This is so because the share of the household income by each household member will be less with more members than those with few members. This conforms to the a priori expectation and other past research work like Nwahia et al. (2012) and Edoumiekumo et al. (2013), that household size has a positive relationship with poverty. Dependency ratio had a positive and significant $(\mathrm{P}<0.05)$ influence on poverty status of farming households in Ebonyi State. This implies that as the variable increases, the probability of a household falling below poverty line (i.e., being poor) increases and vice versa. The coefficient of the dependency ratio is significant at 5\% level of probability and had a positive relationship with poverty. The marginal effect shows that an additional (one) member that depended on the household's head for his/her wellbeing/survival will increase the probability of the household being poor by $3.4 \%$. This could be because the larger the number of less active adults (such as the old or the unemployed) and children in a household the heavier the burden the active members bear in meeting the needs of the household. This is in line with Nwahia et al. (2012).

Sex had a negative and significant $(\mathrm{P}<0.1)$ influence on poverty status of Ebonyi farming households. This means that a household headed by a female will likely be poorer than that headed by the male counterpart. This may be due to the gender inequality that exist among the farming households in Ebonyi both in the resource's allocation. Therefore, households being headed by a female had a positive relationship with poverty. The marginal effect shows that a household being headed by a male will decrease the probability of the household being poor by 9.2\%. This is in line with Anyanwu (2013). Furthermore, Table 3 shows that monthly expenditure by the household negatively influenced poverty status of farming households. The negative and significant $(\mathrm{P}<0.05)$ coefficient of monthly expenditure implies that as the variable increases, poverty of the farming households decreases and vice versa. This is in line with Ogwumike and Akinnibosun (2013). The marginal effect shows that an additional naira to the household's monthly expenditure, will decrease the probability of being poor by $0.5 \%$. In line with a prior expectation, the result in Table 3 further reveals that farm size had a negative and significant $(\mathrm{P}<0.01)$ influence on the poverty status of farming households in Ebonyi State. The coefficient of the farm size is significant at $1 \%$ level of probability and had a positive relationship with poverty. The marginal effect shows that an additional (one) hectare of land cultivated by the respondents will decrease the probability of being poor by $16.6 \%$. This could be because households with larger farm holdings were expected to generate more income, which would enhance their consumption level/income and subsequently improve their household poverty status. This validates the findings of Asogwa, Okwoche and Umeh (2012) and Tsue et al. (2013).

In summary, the factors that had effect on poverty status, in order of importance were farm size (-16.6\%), sex $(-9.2 \%)$, household size $(4.2 \%)$, dependency ratio $(3.4 \%)$ and monthly household expenditure $(-0.5 \%)$. Therefore, $1 \%$ increase in the size of farm land and monthly household expenditure would reduce the probability of a household being poor by $16.6 \%$ and $0.5 \%$ respectively and vice versa. On the other hand, a $1 \%$ increase in the size of the household and dependency ratio would increase the probability of a household being poor by $4.2 \%$ and $3.4 \%$ respectively and vice versa. And lastly, households being headed by a male will reduce the probability of the households being poor by $9.2 \%$ while households being headed by a female will increase the probability of a household being poor by $9.2 \%$ as well.

\section{Conclusion and Recommendation}

The study established that household size, dependency ratio, sex, monthly household expenditure, and farm size were the significant factors that influenced poverty status of Ebonyi State farming households. Also, 54 percent of the Ebonyi farming households were poor while 46 percent of them were non-poor. Therefore, government at the federal, state and local levels should consider the farming households' socioeconomic characteristics in the design and implementation of poverty reduction projects in order to achieve the greatest positive impact on the farming households. Also, government at the various levels should consider setting up programs to address youth unemployment as well as provide social security for aged members of the Ebonyi State society to reduce the dependency burden which have continued to increase poverty level in the State.

\section{References}

Abur CC. 2014. Assessment of Poverty Status Among Rice Farmers in Guma Local Government Area of Benue State, Global Journal of Inter-Disciplinary Social Sciences, 3(4): $122-127$.

Adebayo OO. 2013. Analysis of Poverty Level among Urba Households in Irewole Local Government Area of Osun State. Global Journal of Arts, Human, Social Science, 1(1): $13-19$.

Adetayo AO. 2014. Analysis of Farm Households Poverty Status in Ogun States, Nigeria. Asian Economic and Financial Review, 4(3): 325 - 340.

Anyanwu JC. 2013. Marital Status, Household Size and Poverty in Nigeria: Evidence from the 2009/2010 Survey Data, African Development Bank Working Paper, No. 180, September.

Asogwa BC, Okwoche VA, Umeh JC. 2012. Analysing the Determinants of Poverty Severity among Rural farmers in Nigeria: A Censored Regression Model Approach. American International Journal of Contemporary Research. 2(5): 166 176.

Dorah D. 2015. Investigating the level of Poverty and the means of survival among female-headed Households in a South African Township. Journal of Social Science 45 (1):53 - 59. 
Duniya KP, Rekwot GZ. 2015. Determinants of Poverty among Groundnut Farming Households in Jigawa State, Nigeria. Asian Journal of Agricultural Extension, Economics and Sociology 4(3): 224-230.

Edoumiekumo SG, Karimo TM and Tombofa SS. 2013. Determinants of Households' Poverty and Vulnerability in Bayelsa State of Nigeria. International Journal of Humanities and Social Science Invention. 2(12): 14-23.

Ekong CN, Onye K. 2014. Crowding out Women the Effect of Poverty on Men in Nigeria - A paper presented at the Department of Economics, University of Uyo, Uyo (Seminar Series).

Ekpe I, Alimba JO. 2013. Economics of Rice Production in Ebonyi State South East Nigeria. International Journal of Foods, Agriculture and Veterinary Sciences. 3(2): $77-81$

Eze VA, Odoh NE, Igwe OE, Mgbanya CJ. 2019. Socioeconomic factors influencing poverty among rural households in onicha local government area, ebonyi state, Nigeria, International Journal of Agricultural Research Innovation and Technology 9(1): $8-13$.

Giang TT, Wang G, Yan D. 2014. Evaluation the Factors Leading to Poverty Issue in Central Highlands of Vietnam. Vietnam: Huazhong University of Science and Technology.

Goulden C, D'Aray C. 2014. A Definition of Poverty. London: Joseph Rowntree Foundation.

Ilu IY. 2015. Value Chain Analysis of Rice (Oryza Sativa) In Kano River Irrigation Project (Krip) Kano State, Nigeria. An unpublished Ph.D Thesis, Ahmadu Bello University, Zaria, Nigeria.

Kharas H, Hamel K, Hofer M. 2018. Future Development. The Start of a New Poverty Narrative, an online article on www.brookings.edu, accessed on $12^{\text {th }}$ September, 2019.

Mbanasor JA, Nwachukwu IN, Agwu NM, Njoku ME, Onwumere J. 2013. Analysis of Income Inequality and Poverty Dynamics among Rural Farm Households in Abia State, Nigeria. International Journal of Food and Agricultural Economics. 1(2): 99-106.

National Bureau of Statistics (NBS) 2012. Nigeria Poverty Assessment report: National Bureau of Statistics, Abuja: $18-$ 20.

National Bureau of Statistics (NBS) 2017. Nigeria Poverty Profile. Abuja. NBS Publication 2017, pp: 5 -8.

Nkwede J. 2014. Approaches for Poverty Alleviation and Sustainable Development in Nigeria: A Study of Ebonyi State Community Based Poverty Reduction Agency (EB-CPRA). International Journal of Social Science Studies, 2(1): 153-163.
Nwahia CO, Omonona BT, Onyeabor EN and Balogun SO. 2012. An Analysis of the Effect of Obudu Community Participation in Ecotourism on Poverty. Journal of Economics and Sustainable Development, 3(8): 12-24.

Nwalieji HU. 2015. Comparative Profit Analysis of Rice Production Enterprise among Farmers in Anambra and Ebonyi States, Nigeria. Asian Journal of Agricultural Extension, Economics and Sociology 8(3): 1-1.

Nwaobiala CU, Ume SI. 2013. Economic Analysis of Upland Rice Production in Ebonyi, Southern Agricultural Zone of Ebonyi State, Nigeria. International Journal of Agriculture and Rural Development. 16(2): 1503 - 1508.

Nwinya CE, Obienusi EA and Onuoha DC. 2014. Comparative Economic Analysis of Upland and Lowland RiceProduction in Izzi Local Government Area of Ebonyi State. Journal of Economics and Sustainable Development. 5(17): 144 -160.

Obasi FA, Agbo FU, Onyenekwe SC. 2015. Environmental and socio-economic effects of timber harvesting in Ebonyi State, Nigeria. African Journal of Agricultural Research, 10(11): 1233-1238.

Ogwumike FO, Akinnibosun MK. 2013. Determinants of Poverty among Farming Households in Nigeria. Mediterranean Journal of Social Sciences Published by MCSER-CEMAS-Sapienza University of Rome 4(2): 365 - 373.

Tersoo KS. 2013. An assessment of national poverty eradication programme on wealth creation in Benue State. European Journal of Business and Management. 5(19): 222-239.

Tsue PT, Obekpa JUC, Iorlamen TR. 2013. Analysis of Poverty and its Determinants among Cassava Farmers in Apa Local Government Area, Benue State, Nigeria. Journal of Agricultural Economics and Development. 2(7): 296-300.

Ume SI, Ochiaka CD. 2018. Analysis of Poverty Determinants and the Coping Strategies among Rural Farming Households in Afikpo South Local Government Area of Ebonyi State, Nigeria, Case Studies Journal, 5(9): 129-135.

UNDP, 2013. National Human Development Report. Human Security and Human Development in Nigeria

UNDP, 2016. National Human Development Report 2015. Human Security and Human Development in Nigeria

United Nations 2017. UN Report on Nigeria's Common Country Analysis, CCA. Delivered at Consultative Meeting on the Formulation of the UN Development Assistance Framework (UNDEF IV) for the South East Geo-Political Zone in Awka. Anambra State.

Yousaf H. 2014. Determinants of poverty in Pakistan. Educational Research, 2(5): 192-201.

World Bank 2017. Country Poverty. www.worldbank. org/poverty accessed on 27th March 2018. 